\title{
THE PHYSICAL DEVELOPMENT, EATING HABITS, AND PHYSICAL ACTIVITY OF CHILDREN ATTENDING MUSIC SCHOOL
}

\author{
JUSTYNA FORJASZ ${ }^{1}$, MARIA NOWAK ${ }^{2}$ \\ ${ }^{1}$ Eugeniusz Piasecki University School of Physical Education in Poznań, \\ Faculty of Physical Education in Gorzów Wielkopolski \\ ${ }^{2}$ Szczecin University, Faculty of Physical Culture and Health \\ Promotion, Department of Turism and Recveation
}

\begin{abstract}
Mailing address: Justyna Forjasz, Faculty of Physical Education in Gorzów Wielkopolski, 13 Estkowskiego Street, 66-400 Gorzów Wielkopolski, tel.: +48 95 7279148, fax: +48 957279148 , e-mail: j.forjasz@wp.pl
\end{abstract}

\begin{abstract}
Introduction. Obesity is a multifactorial disorder affecting the energy balance in the body, in which the energy ingested exceeds the energy used by the body over a certain period of time. Some of the key causes of obesity in children include inappropriate eating habits and an insufficient amount of physical activity. The aim of the study presented in this article was to describe the level of physical development, nutritional status, and physical activity of children attending music school, whose free time is more limited than that of their peers. Material and methods. The materials used in the study were anthropometric data and data concerning the body composition of children aged 11-13 years who attended music school and those of their peers who attended regular state school. For the purposes of the study, several nutritional status indicators were established and a questionnaire concerning the eating habits and physical activity of the children was designed. The data were analysed using descriptive statistics. The statistical significance of the differences between the values obtained for the two groups was then measured using a t-test. Results. The children who attended music school were found to be more corpulent and to have more body fat than their peers. It was also determined that the former had irregular meals and an unbalanced diet, and they did not participate in organised out-of-school sports activities. Conclusion. The high amount of body fat found in students of music school was most likely due to their unhealthy eating habits and limited physical activity.
\end{abstract}

Key words: obesity, nutritional status, body composition, children, music school

\section{Introduction}

Nowadays, thanks to the latest technological developments, physical effort is being consciously and consistently eliminated from our daily life. Insufficient physical activity, combined with an improper diet, is causing more and more persons to suffer from overweight and obesity, which are currently some of the key causes of civilisational diseases [1,2] and have severe social and economic consequences. Overweight and obesity are one of the main health threats faced by the citizens of industrialised countries at an increasingly early age [3, 4].

Obesity stems from a long-term positive energy balance, which is caused by ingesting high-calorie foods when the energy provided by them is not used by the body during everyday activity, as well as genetic and environmental factors and some health disorders $[1,2,5]$. Since the lifestyle and working style of young and adult citizens of western societies are not very demanding in terms of physical activity, energy expenditure related to work and daily physical effort is continuously diminishing. Physical effort is being superseded by intellectual work in adults, and children tend to play computer games and watch television instead of playing games or doing sports outdoors, despite the fact that increased physical activity helps reduce the amount of body fat and is a crucial element of a healthy lifestyle. In light of the above, the aim of the current study was to examine the level of physical development, the nutritional status, and the physical activity of children attending music school, whose free time is more limited than that of their peers who attend regular school.

\section{Material and methods}

The participants of the study were 50 boys and 50 girls aged 11-13 years who attended music school. The children were in grades 4-6 and they had been playing musical instruments for 2-6 years. The control group consisted of children attending regular primary state school (tab. 1 and 2). The children had been randomly selected for the study. All of the children came from the Lubuskie Province in Poland.

Since the aim of the study was to examine the physique of the children and their fatness, the following physical features were assessed: body length (body height, trunk length, arm length, and leg length, measured in centimetres), body width (width of the shoulders and pelvis, measured in centimetres), body circumferences (circumferences of the waist, abdomen, hips, upper arm, and thigh, measured in centimetres), body mass (measured in kilograms), and skinfold thickness (measured in millimetres at the upper arm, lower arm, abdomen, thigh, and lower leg, and below the angle of the scapula). The 
measurements were conducted according to the principles accepted in anthropometry, using traditional instruments.

The following nutritional indices were then calculated based on the values obtained in the measurement: Rohrer's index, BMI, the fatness index, and WHR. Mean BMI values obtained for the groups of children of a particular age and gender were then compared with growth charts [6]. Moreover, the participants' body composition was examined using bioelectrical impedance analysis, which made it possible to determine the amount of fat and fat-free body mass. The analysis was performed with a Spectrum Lightweight bioanalyser. The participants' eating habits and physical activity were determined by means of a specially designed questionnaire. The data were analysed using descriptive statistics. Differences in the values obtained for somatic features, body components, and nutritional indices in children attending music school and regular state school of a particular age and gender were tested for statistical significance using a t-test, with statistical significance set at $\mathrm{p}<0.05$.

Table 1. Number of boys and girls involved in the study

\begin{tabular}{|c|c|c|c|c|c|c|c|c|c|c|c|}
\hline \multicolumn{6}{|c|}{ Boys } & \multicolumn{6}{|c|}{ Girls } \\
\hline \multicolumn{3}{|c|}{ Music school students } & \multicolumn{3}{|c|}{ Control group } & \multicolumn{3}{|c|}{ Music school students } & \multicolumn{3}{|c|}{ Control group } \\
\hline 4th grade & 5th grade & 6th grade & 4 th grade & 5 th grade & 6th grade & 4th grade & 5th grade & 6th grade & 4 th grade & 5 th grade & 6th grade \\
\hline 15 & 18 & 17 & 15 & 15 & 20 & 18 & 15 & 17 & 18 & 14 & 18 \\
\hline \multicolumn{3}{|c|}{50} & \multicolumn{3}{|c|}{50} & \multicolumn{3}{|c|}{50} & \multicolumn{3}{|c|}{50} \\
\hline
\end{tabular}

Table 2. Age of the boys and girls involved in the study

\begin{tabular}{|c|c|c|c|c|c|c|c|c|}
\hline & \multicolumn{4}{|c|}{ Boys } & \multicolumn{4}{|c|}{ Girls } \\
\hline & \multicolumn{2}{|c|}{ Music school students } & \multicolumn{2}{|c|}{ Control group } & \multicolumn{2}{|c|}{ Music school students } & \multicolumn{2}{|c|}{ Control group } \\
\hline & Min-max & $\mathrm{M} \pm \mathrm{SD}$ & Min-max & $\mathrm{M} \pm \mathrm{SD}$ & Min-max & $\mathrm{M} \pm \mathrm{SD}$ & Min-max & $\mathrm{M} \pm \mathrm{SD}$ \\
\hline 4th grade & $10.63-11.41$ & $11.03 \pm 0.29$ & $10.51-11.48$ & $11.21 \pm 0.35$ & $10.60-11.40$ & $10.98 \pm 0.30$ & $10.63-11.39$ & $11.02 \pm 0.32$ \\
\hline 5th grade & $11.70-12.40$ & $12.03 \pm 0.25$ & $11.65-12.48$ & $12.12 \pm 0.26$ & $11.47-12.38$ & $11.93 \pm 0.25$ & $11.52-12.50$ & $11.98 \pm 0.26$ \\
\hline 6 th grade & $12.59-13.45$ & $13.09 \pm 0.30$ & 12.64-13.35 & $12.98 \pm 0.21$ & $12.55 \cdot 13.43$ & $12.94 \pm 0.30$ & $12.60-13.48$ & $13.12 \pm 0.32$ \\
\hline
\end{tabular}

\section{Results}

The results of the measurement of somatic features carried out in the group of children from music school and the control group (tab. 3, fig. 1) indicate that the former have a higher body mass. The children from music school who participated in the study were more corpulent and had longer and wider bodies, with greater circumferences, than their peers from the control group. These features were accompanied by a higher level of fatness, as shown by the results of the measurement of skinfold thickness at various sites of the body and the percentage of fat and muscle in the children's body mass. Only the physique of the 12-year-old girls was similar to that of their peers who did not attend music school.

As far as nutritional indices are concerned, the values of Rohrer's index calculated for the music school students showed that they were more corpulent than the control group, the difference being statistically significant; they also had a higher fatness index. The BMI values calculated for the 11- and 13-yearold boys attending music school put them between the 75th and 85th percentiles of the growth chart [6], and the scores of the 12-year-old boys and 11-year-old girls were between the 90th and 95th percentiles. Only the results of the girls from the two older age groups were normal. In contrast, the BMI values of the children who attended regular state school were normal, except for the oldest girls whose scores were between the 75th and 85th percentiles. When it comes to the type of fat distribution, it was found that the boys from music school had a gynoid fat distribution, whereas the girls had an android one. Only the oldest girls from both music and regular schools had a gynoid fat distribution, which was probably caused by the fact that they had started puberty.

The results obtained regarding the eating habits and level of physical activity of children attending music school are shown in table 4. It was found that the children, particularly the boys, did not eat regularly and most of them had three meals a day. Fruits and vegetables were most frequently consumed in one meal or not at all. The children ate between meals, consuming especially sweets and crisps, and tended to have fizzy drinks. Almost $40 \%$ of the children surveyed had fast food twice a week. The children declared they did not participate in organised out-of-school sports activities and only engaged in sports during their PE classes, although 5 of the students did not attend these classes. They said they spent their free time playing a musical instrument and using multimedia.

\section{Discussion}

Overweight and obesity have currently become civilisational diseases. In many countries, including Poland, the incidence of obesity has grown in the past several decades. Obesity is a multifactorial disorder which affects the energy balance in the body and occurs when the energy provided in the food consumed exceeds the energy used by the body over a certain period of time. As a consequence, the body stores excessive energy in the form of adipose tissue [7]. It is estimated that currently 22 million children aged less than 5 years are overweight worldwide [1]. Research [8] conducted in Poland has shown that the weight of $60 \%$ of adult men and $50 \%$ of adult women is excessive. As far as younger populations are concerned, $16 \%$ of boys and $11 \%$ of girls are overweight, and $4 \%$ and $3.5 \%$ are obese, respectively. Excessive weight has been found to be more prevalent in the youngest age groups, and its incidence tends to diminish with age, especially as far as obesity is con- 
cerned [8]. The music school students who participated in the current study were on average 3-6 cm taller than the average child living in the Lubuskie Province [9], but their body mass was much higher than the norm: it was 9-11 kg higher for the boys and 12-15 kg higher for the girls. Only the 12-year-old girls in the group had relatively lean bodies.

Table 3. Physical features of the boys and girls involved in the study

\begin{tabular}{|c|c|c|c|c|c|c|c|c|c|c|c|c|}
\hline \multirow{3}{*}{$\begin{array}{c}\text { Physical feature } \\
\text { Age }\end{array}$} & \multicolumn{6}{|c|}{ Boys } & \multicolumn{6}{|c|}{ Girls } \\
\hline & \multicolumn{3}{|c|}{ Music school students } & \multicolumn{3}{|c|}{ Control group } & \multicolumn{3}{|c|}{ Music school students } & \multicolumn{3}{|c|}{ Control group } \\
\hline & 11 & 12 & 13 & 11 & 12 & 13 & 11 & 12 & 13 & 11 & 12 & 13 \\
\hline Trunk length & 44.74 & 48.26 & 51.56 & 48.19 & 49.82 & 50.33 & 43.30 & 43.86 & 50.08 & 43.96 & 47.41 & 47.99 \\
\hline Arm length & 67.51 & 68.21 & 73.57 & 64.10 & 66.30 & 68.35 & 66.90 & 72.31 & 76.14 & 63.54 & 67.50 & 69.99 \\
\hline Leg length & 76.39 & 78.03 & 85.93 & 72.16 & 74.48 & 77.67 & 77.94 & 85.90 & 84.34 & 74.86 & 78.60 & 80.79 \\
\hline Shoulder width & 32.64 & 32.88 & 32.15 & 30.80 & 31.52 & 32.25 & 29.64 & 28.50 & 30.31 & 29.38 & 29.87 & 31.21 \\
\hline Pelvis width & 26.36 & 28.13 & 28.55 & 22.21 & 22.56 & 22.59 & 27.43 & 24.85 & 27.63 & 21.72 & 22.17 & 23.94 \\
\hline Waist circumference & 69.00 & 78.06 & 74.10 & 67.21 & 70.22 & 72.12 & 71.79 & 74.00 & 70.31 & 63.06 & 65.32 & 66.57 \\
\hline Abdominal circumference & 72.71 & 80.25 & 77.00 & 67.92 & 71.59 & 69.72 & 76.29 & 69.15 & 78.75 & 65.76 & 66.18 & 69.79 \\
\hline Hip circumference & 85.43 & 93.25 & 87.50 & 77.03 & 80.21 & 78.19 & 85.64 & 82.20 & 92.00 & 77.50 & 78.44 & 87.35 \\
\hline Upper arm circumference & 24.36 & 27.94 & 25.30 & 22.52 & 23.15 & 22.81 & 25.21 & 21.10 & 24.63 & 22.61 & 22.37 & 23.53 \\
\hline Thigh circumference & 44.71 & 54.38 & 50.30 & 45.49 & 47.97 & 45.59 & 49.36 & 37.55 & 49.13 & 46.28 & 47.42 & 52.12 \\
\hline Subscapular skinfold thickness & 13.57 & 22.00 & 16.20 & 8.01 & 8.43 & 8.99 & 17.00 & 8.50 & 16.00 & 8.43 & 11.01 & 10.40 \\
\hline Upper arm (triceps) skinfold thickness & 10.43 & 16.57 & 13.80 & 10.88 & 10.44 & 10.89 & 17.71 & 7.20 & 16.13 & 11.21 & 12.41 & 11.90 \\
\hline Forearm skinfold thickness & 12.00 & 15.71 & 13.00 & 8.05 & 7.78 & 8.17 & 15.29 & 7.10 & 16.38 & 8.31 & 9.11 & 8.64 \\
\hline Abdominal skinfold thickness & 17.14 & 25.43 & 19.20 & 7.51 & 7.31 & 8.92 & 24.29 & 11.90 & 17.88 & 7.35 & 9.60 & 9.91 \\
\hline Thigh skinfold thickness & 25.29 & 34.57 & 26.80 & 16.01 & 15.65 & 18.05 & 34.57 & 14.70 & 29.50 & 15.85 & 18.89 & 19.60 \\
\hline Lower leg skinfold thickness & 18.86 & 30.71 & 22.40 & 13.60 & 13.15 & 15.98 & 29.00 & 13.20 & 25.75 & 13.09 & 14.55 & 16.15 \\
\hline Body fat percentage & 30.95 & 43.74 & 34.66 & 22.54 & 21.18 & 24.45 & 40.99 & 22.43 & 38.51 & 22.49 & 26.68 & 23.24 \\
\hline Body muscle percentage & $\overline{69.05}$ & $\overline{56.26}$ & $\overline{65.34}$ & 77.46 & 78.82 & 75.55 & $\overline{59.01}$ & 77.57 & $\overline{61.49}$ & 77.51 & 73.32 & 76.76 \\
\hline BMI & 20.15 & 22.16 & 20.58 & 17.87 & 18.82 & 18.11 & 22.98 & 17.03 & 20.09 & 18.09 & 17.60 & 21.85 \\
\hline Rohrer's index & 1.32 & 1.44 & 1.24 & 1.21 & 1.24 & 1.16 & 1.53 & 1.08 & 1.23 & 1.24 & 1.15 & 1.39 \\
\hline $\begin{array}{l}\text { Fatness index (thigh circumference/body } \\
\text { height }{ }^{*} 100 \text { ) }\end{array}$ & 29.40 & $\underline{35.32}$ & $\underline{30.33}$ & 30.72 & 31.54 & 29.23 & 32.65 & $\underline{23.74}$ & 29.94 & 31.78 & 31.06 & 33.16 \\
\hline WHR & 0.81 & 0.84 & 0.85 & 0.87 & 0.88 & 0.92 & 0.84 & 0.90 & 0.76 & 0.81 & 0.83 & 0.76 \\
\hline
\end{tabular}

Statistically significant differences $(\mathrm{p}<0.05)$ between children attending music school and those attending regular school (the control group) of the same age and gender have been underlined.
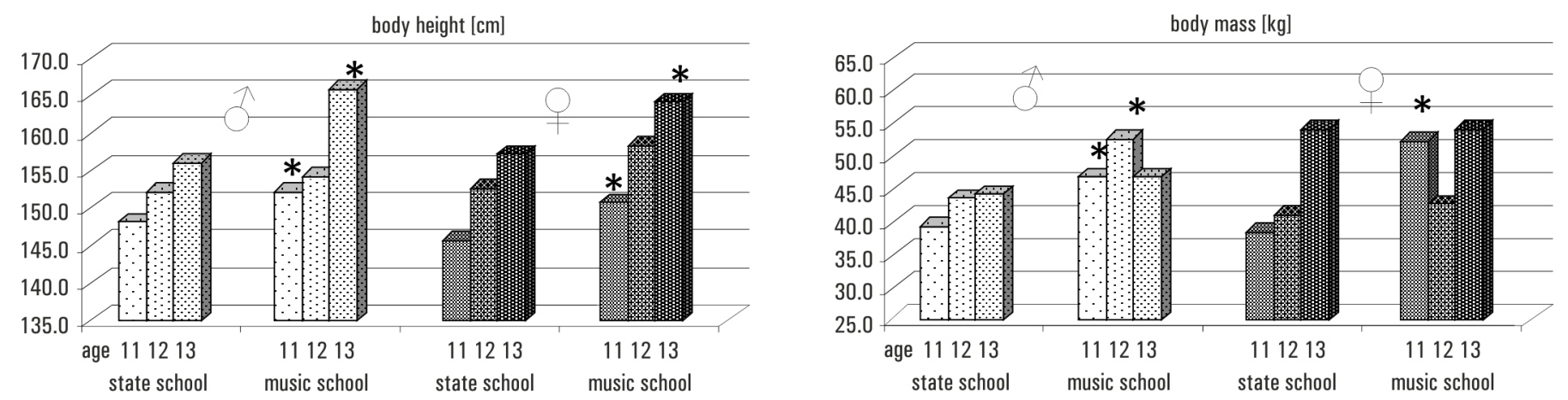

Statistically significant differences $(p<0.05)$ between children attending music school and those attending regular school of the same age and gender have been underlined.

Figure 1. Chart illustrating the body height and mass of the children involved in the study

The participants' body mass impacted the values of their BMI, an index which serves as a basic indicator of nutritional status $[2,10,11]$. Research has revealed that BMI values above the 90th percentile found in children most often correlate with overweight and obesity in adulthood. In the group of music school students this index clearly exceeded the norm provid- ed in growth charts, putting the values obtained by some of the children between the 90th and 95th percentile, as well as the one defined for the Lubuskie Province, where the children lived [9]. An analysis of the values of Rohrer's index calculated for the children attending music school confirmed their corpulence; they had a statistically significantly higher amount of 
Table 4. Results of the questionnaire regarding eating habits and leisure time activity carried out among music school students

\begin{tabular}{|c|c|c|c|c|c|}
\hline \multirow{2}{*}{ Question } & \multirow{2}{*}{ Answer } & \multicolumn{2}{|c|}{ Boys } & \multicolumn{2}{|c|}{ Girls } \\
\hline & & $\mathbf{N}$ & $\%$ & $\mathbf{N}$ & $\%$ \\
\hline \multirow{3}{*}{ Do you eat regularly? } & Yes & 5 & 10 & 12 & 24 \\
\hline & No & 40 & 80 & 23 & 46 \\
\hline & Not always & 5 & 10 & 15 & 30 \\
\hline \multirow{5}{*}{$\begin{array}{l}\text { How many meals do } \\
\text { you have per day? }\end{array}$} & 2 & 5 & 10 & 1 & 2 \\
\hline & 3 & 32 & 64 & 35 & 70 \\
\hline & 4 & 8 & 16 & 10 & 20 \\
\hline & 5 & 3 & 6 & 2 & 4 \\
\hline & More & 2 & 4 & 2 & 4 \\
\hline \multirow{4}{*}{$\begin{array}{l}\text { How many of your } \\
\text { meals contain fruit } \\
\text { and vegetables? }\end{array}$} & Three & 0 & 0 & 0 & 0 \\
\hline & Two & 2 & 4 & 3 & 6 \\
\hline & One & 26 & 52 & 24 & 48 \\
\hline & Fewer & 22 & 44 & 23 & 46 \\
\hline \multirow{3}{*}{$\begin{array}{l}\text { Do you eat between } \\
\text { meals? }\end{array}$} & Yes & 43 & 86 & 50 & 100 \\
\hline & No & 2 & 4 & 0 & 0 \\
\hline & Yes, but only sometimes & 5 & 10 & 0 & 0 \\
\hline \multirow{6}{*}{$\begin{array}{l}\text { What do you drink the } \\
\text { most often? }\end{array}$} & Fizzy water & 0 & 0 & 0 & 0 \\
\hline & Still water & 4 & 8 & 5 & 10 \\
\hline & Fruit juice & 4 & 8 & 6 & 12 \\
\hline & Vegetable juice & 0 & 0 & 0 & 0 \\
\hline & Fizzy drinks & 42 & 84 & 38 & 76 \\
\hline & Tea & 0 & 0 & 1 & 2 \\
\hline \multirow{5}{*}{$\begin{array}{l}\text { How many times } \\
\text { during the week do } \\
\text { you have fast food? }\end{array}$} & Once & 12 & 24 & 25 & 50 \\
\hline & Twice & 21 & 42 & 18 & 36 \\
\hline & Three times & 9 & 18 & 2 & 4 \\
\hline & More than three times & 3 & 6 & 0 & 0 \\
\hline & Never & 5 & 10 & 5 & 10 \\
\hline \multirow{7}{*}{$\begin{array}{l}\text { What food do you } \\
\text { buy the most often } \\
\text { from the shop at your } \\
\text { school? }\end{array}$} & Sweet buns & 13 & 26 & 6 & 12 \\
\hline & Drinks & 15 & 30 & 14 & 28 \\
\hline & Chocolate bars & 10 & 20 & 12 & 24 \\
\hline & Chewing gum & 2 & 4 & 7 & 14 \\
\hline & Crisps & 8 & 16 & 6 & 12 \\
\hline & Other & 0 & 0 & 0 & 0 \\
\hline & I don't buy anything. & 2 & 4 & 5 & 10 \\
\hline \multirow{3}{*}{$\begin{array}{l}\text { Do you attend PE } \\
\text { classes and do sports } \\
\text { in your leisure time? }\end{array}$} & No & 4 & 8 & 1 & 2 \\
\hline & I only attend PE classes & 45 & 90 & 49 & 98 \\
\hline & $\begin{array}{l}\text { I both attend PE classes and } \\
\text { do sports in my leisure time }\end{array}$ & 1 & 2 & 0 & 0 \\
\hline \multirow{6}{*}{$\begin{array}{l}\text { How do you spend } \\
\text { your leisure time the } \\
\text { most often? }\end{array}$} & Watching TV & 15 & 30 & 3 & 6 \\
\hline & Using the computer & 12 & 24 & 8 & 16 \\
\hline & In an active way & 1 & 2 & 0 & 0 \\
\hline & Reading books & 1 & 2 & 4 & 8 \\
\hline & Seeing my friends & 4 & 8 & 5 & 10 \\
\hline & Playing a musical instrument & 17 & 34 & 30 & 60 \\
\hline
\end{tabular}

subcutaneous adipose tissue than the control group. Another important feature of excessive weight is fat distribution, assessed in clinical practice by calculating the waist-to-hip ratio (WHR), which makes it possible to determine whether someone is suffering from central or gynoid obesity. Due to sex differences, men tend to have android obesity and women typically have gynoid obesity. The gynoid type of obesity observed in the boys from music school indicates that their body fat is not normally distributed, but it is distributed in a way that is typical of obese children. The gynoid distribution of fat found in the older groups of girls is typical of that found in adult women. Cross-sectional analyses did not make it possible to establish whether or not these results had to do with puberty; it is, however, possible to determine the distribution of fat in the human body as early as at the age of 7 years [12].

Childhood obesity is very rarely due to endocrine disorders, which cause less than 1\% of children to be obese. As many as 90-95\% of obese children suffer from simple obesity stemming from an excessive energy intake that is not counterbalanced by a sufficient amount of physical activity. Obesity is caused both by endogenous factors and environmental factors, such as a particular person's lifestyle and level of physical activity. Children inherit only approximately $30 \%$ of factors influencing their energy balance, such as the basal metabolic rate, the capacity of the body to burn excessive calories, and the distribution of fat in the body [7]. If both parents are obese, the risk that the child will be obese is $80 \%$, while for children whose one parent is obese the risk of developing obesity is estimated to be $40 \%[2,13]$.

Some of the key causes of childhood obesity in children include unhealthy eating habits and limited physical activity. The eating habits that children develop during childhood have a crucial impact on whether or not their weight will become excessive. Families whose members are obese usually have a high-calorie diet and consume significant amounts of fats, carbohydrates, and salt, at the same time eating insufficient amounts of fruits and vegetables. They tend to have their meals irregularly, consuming snacks between meals, and to eat quickly, which causes them to feel satiated only after they have had large portions of food. Main meals are often replaced with high-calorie fast food, and sugar-laden soft drinks are frequently consumed [14]. The habits of the music school students who participated in the study followed these patterns to a large extent. The students tended to eat irregularly, three times a day, consuming small amounts of fruits and vegetables and having snacks between meals, most often in the form of sweets. These unhealthy eating habits are the most probable cause of the children's overweight and obesity, particularly considering the fact that they barely consumed any fruits or vegetables and often had food that was high in calories and low in fibre.

The best way to deal with the issue of obesity is to prevent it in childhood, among others by making sure that children follow the principles of healthy eating, such as eating a certain number of meals at certain times during the day, but also that they undertake sufficient physical activity $[1,5,15]$. It is important to raise young people's awareness with respect to these issues [16]. The music school students most probably developed a body type characterised by a high body mass, increased circumferences of different parts of the body, and a considerable amount of body fat due to improper eating habits and limited physical activity, which not only the children themselves but also their parents and educators are to be blamed for [16]. The students only undertook physical activity during their PE classes and were not active in their leisure time. Only one boy in the group declared he took part in out-of-school sports activities. It is important to note that if children are not encouraged to engage in physical activity and derive satisfaction from it both by their parents and teachers, they are very likely to continue to be physically inactive in adult life. Research involving American children has shown that spending time in a passive way watching TV or using the computer for more than 2 hours a day significantly increases the risk of that a person will become obese [14]. Studies conducted on European children whose physical activity was limited to one hour a day revealed that these children had a significantly higher amount of body fat than their peers who spent more than two hours a day being 
physically active [17]. If a person does become obese as a child, they are at a very high risk of being obese as an adult, and this risk is as high as $77 \%$ according to Steinberger et al. [18].

Overweight and obesity, the latter in particular, can pose a serious threat to a person's health and life. They not only have serious medical consequences, such as cardiovascular diseases, lipid and insulin disorders, motor development disorders, and locomotor system diseases [18, 21, 22]. They also have psychosocial and professional consequences, which include low self-esteem, anxiety and depression, social withdrawal, difficulty in socialising with others, and the tendency to reduce tension through overeating [19]. Obese persons are often perceived as physically and sexually unattractive and as mentally weak [20]. The health issues experienced by children and adolescents can thus have a direct impact on the way they will function in society in the future. If the harmful effects of obesity are to be avoided and young people are to grow and develop in a healthy way, they need to have good eating habits and undertake a sufficient amount of physical activity. Nurturing the hobbies and interests of children, such as their passion for playing musical instruments, one should not forget to make sure they follow the principles of a healthy lifestyle so that they can be healthy in their youth and adulthood.

\section{Conclusion}

1. The children attending music school who participated in the study were more corpulent and had longer and wider bodies, with greater circumferences, than their peers from the control group. These features were accompanied by a higher level of fatness, as shown by the results of the measurement of skinfold thickness at various sites of the body and the percentage of fat and muscle in their body mass.

2. The students had irregular meals, containing low amounts of vegetables and fruits, and had snacks between meals. They spent their free time playing an instrument and using multimedia rather than participating in organised out-ofschool sports activities.

3. The high amount of body fat found in the students was probably due to a great extent to their unhealthy eating habits and limited physical activity.

\section{Bibliography}

1. Kosti R.I., Panagiotakos D.B. (2006). The epidemic of obesity in children and adolescents in the world. Central European Journal of Public Health 14(4), 151-159. PMID:17243492

2. Lenart-Domka E., Kwolek A. (2007). Is it necessary for obese children to undergo physical therapy? Przeglad Medyczny Uniwersytetu Rzeszowskiego 1, 99-105. [in Polish]

3. Freedman D., Dietz W.H., Srinivasan S.R., Berenson G.S. (1999). The relation of overweight to cardiovascular risk factors among children and adolescents. The Bogalusa Heart Study. Pediatrics 103(6), 1175-1182. PMID:10353925

4. Kopelman P.G. (2000). Obesity as a medical problem. Nature 404 (6778), 635-643. DOI:10.1038/35007508

5. Białkowska M. (2011). Etiopathogenesis of obesity. Postępy Nauk Medycznych 9, 765-769. [in Polish]

6. Kuczmarski R.J., Ogden C.L., Grummer-Strawn L.M., Flegal K.M., Guo S.S., Wei R. et al. (2000). CDC Growth Charts. Advance Data 8(314), 1-27. PMID:11183293

7. Rang H.P., Dale M.M., Ritter J.M. (2001). Clinical pharmacology (vol. 1). Lublin: Wydawnictwo Medyczne Czelej. [in Polish]

8. Jarosz M., Kłosiewicz-Latoszek L., Charzewska J.,
Białkowska M. (2010). Diagnosis of nutritional status disorders in medical practice and care. Warsaw: Instytut Żywności i Żywienia. [in Polish]

9. Malinowski A., Sienkiewicz R., Tatarczuk J., Stuła A., Wandycz A. (2005). Physical development of children in the Lubuskie Province. Zielona Góra: Oficyna Wydawnicza Uniwersytetu Zielonogórskiego. [in Polish]

10. Mei Z., Grummer-Strawn L.M., Pietrobelli A., Goulding A., Goran M.I., Dietz W.H. (2002). Validity of body mass index compared with other body-composition screening indexes for the assessment of body fatness in children and adolescents. American Journal of Clinical Nutrition 75(6), 978985. PMID:12036802.

11. Socha P., Socha J. (2003). Simple obesity and its prevention. Pediatrics International 78(1), 7-13. DOI:10.1016/j. pepo/635584 [in Polish]

12. Chrzanowska M., Suder A., Kruszelnicki P. (2012). Tracking and risk of abdominal obesity in the adolescence period in children aged 7-15. The Cracow longitudinal growth study. American Journal of Human Biology 24, 62-67. DOI:10.1002/ajhb.22204

13. Garn S.M., La Velle M. (1985). Two decade follow-up of fatness in early childhood. American Journal of Diseases of Children 139(2), 181-185. DOI:10.1001/archpedi.1985.02140040083033

14. Kiess W., Muller G., Kapellen T., Bottner A. (2001). Obesity in childhood and adolescence: epidemiology, etiology, clinical diagnosis and management. International Seminars in Pediatric Gastroenterology \& Nutrition 10(4), 3.

15. Levy T.S., Ruán C.M., Castellanos C.A., Coronel A.S., Aguilar A.I., Humarán I.M.G. (2012). Effectiveness of a diet and physical activity promotion strategy on the prevention of obesity in Mexican school children. BMC Public Health 12, 152. DOI:10.1186/1471-2458-12-152

16. Power T.G., Bindler R.C., Goetz S., Daratha K.B. (2010). Obesity prevention in early adolescence: student, parent, and teacher views. Journal of School Health 80(1), 13-19. DOI:10.1111/j.1746-1561.2009.00461.x

17. Ekelund U., Sardinha L.B., Anderssen S.A., Harro M., Franks P.W., Brage S. et al. (2004). Associations between objectively assessed physical activity and indicators of body fatness in 9- to 10-y-old European children: a population-based study from 4 distinct regions in Europe (the European Youth Heart Study). American Journal of Clinical Nutrition 80(3), 584-590. PMID:15321796

18. Steinberger J., Moran A., Hong C.P., Jacobs D.R. Jr, Sinaiko A.R. (2001). Adiposity in childhood predicts obesity and insulin resistance in young adulthood. Journal of Pediatrics 138(4), 469-473. DOI:10.1067/mpd.2001.112658

19. Serpil E., Nurcan C., Muge T., Nagehan B., Fisun A., Damla G. (2004). Is obesity a risk for psychopathology among adolescents? Pediatrics International 46(3), 296-301. DOI:10.1111/j.1442-200x.2004.01882.x

20. Puhl R., Brownell K.D. (2001). Bias, discrimination, and obesity. Obesity Research 9(12), 788-805. Review. PMID:11743063

21. Freedman D.S., Khan L.K., Dietz W.H., Srinivasan S.R., Berenson G.S. (2001). Relationship of childhood obesity to coronary heart disease risk factors in adulthood: the Bogalusa Heart Study. Pediatrics 108, 712. DOI:10.1542/ peds.108.3.712.

22. Must A., Anderson S.E. (2003). Effects of obesity on morbidity in children and adolescents. Nutrition in Clinical Care 6(1), 4-12. PMID:12841425

Submitted: November 12, 2014

Accepted: July 16, 2015 